\title{
Towards an Alternative Development Paradigm for Africa
}

\author{
Abonyi Nichodemus Nnaemeka \\ Department of Political Science, Eungu State University of Science and Technology, Enugu, Nigeria
}

KEYWORDS Economy. Politics. Development. Modernism. Environments

\begin{abstract}
Viewed from the economic and political prisms, Africa is known to have been wantonly marginalized both in the world economy and in the area of development. This marginalization, which is also a restatement of the underdevelopment of the continent or what some refer to as the development of the underdevelopment of the continent has found evidence in the increasing regression of the economy of the continent and its diminishing importance or relevance in the world economy, particularly to the industrialized countries. The statistics of Africa's role in the global economy make the point clearer enough. Africa's share of exports in world trade, for instance, which was 2.4 per cent in 1970 , dwindled to 1.4 per cent by 1990 . Even its share of non-oil primary commodities fell from 7 per cent to less than 4 per in the same period. The consequences of the foregoing grim statistics has found expression in crushing external debt burden, poverty, squalor, hunger and disease and general underdevelopment. This paper, based on the conclusion that Africa is being marginalized in the world economy and development, charted a course for an alternative development paradigm other than that based on the modernization theory or other grand development paradigms, models or strategies. The paper concluded that this alternative paradigm should draw largely from the post-modernism paradigm that accommodates the prevailing circumstances of the various environments.
\end{abstract}

\section{INTRODUCTION}

What is the discourse on the marginalization of Africa saying? What exactly does the marginalization of Africa means? What is being said is quite clear and simple. The concern is mainly (but not exclusively) with economic marginalization, with the economic regression of Africa relative to other regions of the world and the diminishing importance and relevance of Africa to the global economy, particularly to the industrialized countries. The statistics of Africa's role in the global economy make the point well enough. Africa's share of exports in world trade, which was only 2.4 percent in 1970 , was down to 1.4 percent by 1990 . Even its share of non-oil primary commodities fell from 7 percent to less than 4 percent in the same period (Serageldin 1993: 95). That is why Africa was deservedly voiceless at the GATT negotiations and quite predictably came out worse than any other region. A 1993 study for the World Bank and the OECD Development Center estimates that, on account of the GATT agreement, the world will be at least $\$ 213$ billion richer a year by 2002, whereas SubSaharan Africa will be $\$ 2.6$ billion a year poorer. (Goldin et al. 1993).

How can one account for the problem of marginalization? Perhaps. It is not necessary to do so, because the problem is more apparent than real. What is popularly called the problem of marginalization is essentially a restatement of the perennial problem of underdevelopment. Marginalization is in reality the dynamics of underdevelopment, the development of underdevelopment by the agents of development. According to the World Bank, the average annual growth rate of GNP per capita for Africa was 1.3 percent between 1980 and 1990 and -0.6 percent in 1991 (World Bank 1993a: 179). Average agricultural (weighted) growth rate for 1970 to 1980 in Africa was 1.5 percent. With population growth rate averaging above 3 percent, Africa has become food-dependent and prone to chronic malnutrition. Industrial value added has been virtually stagnant. The 1989 long-term perspective study by the World Bank, SubSaharan Africa: From Crisis to Sustainable Growth, set a target of 5 percent value added for 1990 and then 7 percent (World Bank 1989b: 1)

In these circumstances, Africa has become heavily indebted. Sub-Saharan Africa's debt as a percentage of GNP was 28.6 percent in 1980 and 107.9 percent in 1991. As a percentage of total exports it was 96.6 percent in 1980 and 329.4 percent in 1991. Debt service as a percentage of exports was 10.9 percent in 1980 and 20.8 percent in 1981. (World Bank 1993e: 285). Africa can neither pay its debts nor grow out of them.

For the most part, Africa has been stagnating or regressing economically. It has, therefore, become unattractive to foreign investors, unable to import or export much and as a virtual nonentity in world trade, and increasingly unable to elicit 
the interest of other regions. The decline is not just a cause of marginality; it is also the process of marginalization. The discourse on marginalization is really about the deepening crisis of underdevelopment.

Goran Hyden, the social scientist, states in the conclusion of his book, Beyond Ujamaa in Tanzania (1980), that the development problematic of Africa is unique. He argues that it offers a challenge to the conventional paradigms or models, as presented by the social sciences. By focusing almost exclusively on the nature of international economic relations as the cause of underdevelopment. these paradigms - in Hyden's view put the cart before the horse. They fail to account for the historical uniqueness of Africa, notably the pre-capitalist, pre-colonial social relations, represented by the uncaptured peasantry. Hyden's argument is that small is powerful, considering the social autonomy of the peasants who are and remain the primary challenge to development in Africa today. The African peasantry, due to its pre-modern economic power, holds development at bay. An inventive, alternative approach is required, according to Hyden who wrote in 1980.

About five years later, in 1986, an important seminar took place in Uppsala, Sweden. Its purpose was to provide a platform for a crosssection of Africa scholars and leaders, which included A.M. Babu, Joseph Ki-Zerbo, Changa Macho, Wamba and Goran Hyden. They were to discuss alternative development strategies for Africa's future. The seminar was significant because it sought an African, rather than a Third World, perspective on the continent's situation, and because it singled out "the state" in Africa for frank discussion, and to think the unthinkable (Development Dialogue 1987: 2).

Within this context, it is worth noting that three great principles were inherited from traditional, pre-colonial times. First, power was limited by custom and tradition, it being assigned to defined roles and positions. At the same time freedom of expression was guaranteed according to strictly respected codes, and political power was distinct from economic power, as among the Bambara and the Baganda. Second, throughout Africa power was shared between nobles and ordinary people, between warriors and peasants. Finally, the rule of law was supreme; even kings were subordinate to it.

Colonialism undermined these three principles.
It had all started with the slave-trade, which reinforced the kinship system as the most valued (social) defence of the Africa. The slave-trade equally prevented formation of political structures and social attitudes congruent with statehood and citizenship. Colonialism thereafter introduced statehood abruptly in a cultural vacuum. It also separated the state and society, and thereby deprived the state of the morality of African society. The state became an amoral entity. In post-colonial times the state has no chance to develop independently. It was held at bay by a small middle class and manipulated by unscrupulous leaders, who made a mockery of democracy and of human development An alternative perspective is needed, the seminar argued, that liberates the besieged state from internal and external constraints. There is need for another development, involving self-reliance and co-operation, and reducing foreign aid addiction. An alternative perspective is needed to limit the power of the African state, which has become one of the greatest obstacles to development in Africa, change is required that encourages sharing of power and the rule of law. Finally, the state has been overloaded being the sole agency of development, the sole entrepreneur, the sole decision-maker and executioner.

The ideas discussed at the Uppsala seminar in 1986 found a more emphatic expression - again five years later in the African Charter for Popular Participation and Transformation (Arusha 1990). Underlying the charter was a vision of a new Africa. This vision seeks to advocate human development and economic justice, democracy and accountability and above all popular participation. At the same time it vows to fight despotism, authoritarianism and klepetocracy.

In conclusion, we may bring the various threads together. The development problematic of Africa is unique because the state has developed in virtual isolation of society. As such, it has immorally denied the population social as well as economic justice. Another development is required involving a second liberation, which will free the people to participate in their own development.

\section{Theoretical Framework}

This discourse is anchored against the background of the modernization theory championed by theorists led by Rostow (1960) and Postmodernism. In a nutshell, this modernization legacy 
(including liberal and "Keynesian schools, which differ on the role of the state) can still be seen clearly in terms of:

- assumptions reflecting a continuing implicit belief in the validity of linear stages of development

- cultural imperialism, in terms of a continuing belief in the superiority of Western ideas, values, expertise and policies, which poor, indebted countries should follow in order to escape poverty, debt and 'underdevelopment'.

- reliance on universalizing/globalising methods which reflect a belief that ideas and policies that worked in Europe and North America some decades ago should be equally valid anywhere in the world, regardless of different politico-economic or cultural circumstances.

- continued belief in the value and at least implicit superiority of Euro-American intellectual history and philosophy, rather than an openness to drawing on the diverse histories and approaches indigenous to various parts of the world.

On the other hand, the essence of postmoderm intellectual practice is a rejection of the universalizing grand theories (so-called 'metanarratives' or 'meta-theories') that characterized modernist thinking with its roots in the Enlightenment and ideas of 'rational man' all in a very Euro-centric historical sense. Instead, it argues that different cultures and stakeholders have their own philosophies, theories and rationalities, sometimes apparently contradictory to one another but ultimately all having validity in context. In development studies and development policy, the implication is that all stakeholder groups, bring something of value to the table, so to speak, and that the traditional top-down dominance of western, expert-led science, technology and rationality however imposed and which has led to so many and such widespread development failure, alienation and environmental unsustainability is untenable. Instead, post-modern praxis emphasizes a new pluralism, involving mutual respect and negotiation in search of consensus or at least a more inclusive solution in which indigenous approaches and the ideas, values and aspirations of the supposed beneficiaries of 'development' are taken account of and included. Ideally, some convergence or new synthesis, taking the most appropriate elements of local and global ideas, and practices may emerge as a new hybrid or syncretism.

\section{Literature Review}

For quite a long time now the debate on the appropriate model or strategy to implement economic development in Africa has raged on polarizing the theorists into two camps: the liberal/ modernization theorists and the radical/ dependency theorists. What are the postulations of these theorists?

The modernization theory has its origin with the major work of Rostow (1960), The Stages of Economic Growth: A Non-communist Manifesto. In the work, Rostow outlined five stages every development community must go through or break out of in the process or quest for economic development, namely, the traditional society, the precondition of take-off, the drive to maturity, and the age of mass consumption.

Extrapolating from the above, Rostow and his fellow modernization theorists categorized Third World Societies into the first stage as purely a traditional society mostly preoccupied with glorification or veneration of their traditional values, beliefs and ethos, and that unless they break away from or abandon traditionalism and embrace the Calvinist cult (Western values) they cannot find themselves among the world's industrialized nations. The implication of the modernization theory is that the West should play key role in the economic development of poor countries and that the West do this by assisting in population control, increasing food production, introducing industrial technology and providing foreign aid. All these involve heavy importing of goods from the West. As Offiong (2001) argues, increasingly the modernization theory has fallen short of its own standard of success, since global inequality, particularly as it affects the Third World is still endemic after several decades of applying the modernization strategy.

In fact, Offiong (2001) has criticized the modernization theory on the following grounds:

- The theory outrightly ignores the global forces that have continued to stifle the Third World's efforts at development, namely, the political and economic barriers to development which have surfaced since the advent of the Industrial Revolution.

- The theory treats Third World societies as self-contained units, whose political, social, or economic systems can be analyzed in themselves.

- The theory presents the West as the standard 
by which the whole world should be judged, thereby betraying an Euro-centric bias

- The theory reified the nation-state as the only unit of analysis, by assuming that all societies can follow a single path of evolutionary development from tradition to modernity, while ignoring the world-historical development of transitional structures that constrain or prompt national or local development along diverse as well as parallel paths.

- The theory got so obsessed with Third World traditionalism so much that it not only exaggerated its influence on the development efforts but led the theorists to construct a pejorative conception of the word 'tribe' which is but a variant of the notion of nation-state. What then do the dependency/radical theorists say? The dependency theory actually has its origin from the work of Paul Baran, The Political Economy of Growth issued in 1957. Baran's argument is that the industrialized societies of the West were responsible for the poverty and lack of economic development prevalent in most parts of the Third World, thus making it difficult for the later to break out of poverty. He further argues that the Western societies do this by fostering organic alliance between the bourgeoisie of the West, on one hand, and the modernizing local elite, on the other hand. Baran concluded that the modernizing elite rule their societies in favour of and under the dictates of the bourgeoisie of the industrialized societies.

As Offiong (2001: 44) surmised, the difference between the modernization theory and the dependency theory is the latter explains global inequality in terms of the historical exploitation of poor societies by the rich and powerful ones. According to him, the dependency theory rejects the basic assumption by the modernization theorists that the unit of analysis in studying underdevelopment is the national society.

Theotonio Dos Santos cited in Cockcroft defines dependency as:

"a situation in which a certain group of countries have their economy conditioned by the development and expansion of another economy to which the former is subject" (Theotonis Do Santos as cited by Cockcroft 1972: $71-2)$.

From the above definition of dependency, it is clear that the dominant countries are capable of a dynamic form of development responsive to their internal needs, whereas the dependent ones have a reflex type of development, that is, one both constrained by its incorporation into the global economic system and which results from its mere adaptation to the requirement of the expansion of the dominant economies. In summary, and as David Mckay (cited in Offiong 1980a: 76) has observed, "dependency means... that the development alternatives open to the dependent nations are defined, constrained or limited by its integration into and function within the world market system. That Africa, as Offiong (2001: 46) has admitted, has an economic relationship with the West is never a bad idea, for, nobody advocates autarky. However, what is bad and worrisome is that over four decades of such economic relationship has only increasingly mired Africa into endemic poverty, inequality and underdevelopment. As the author also concluded the over three decades of preoccupation with the West's development strategy in Africa have yielded meager returns: stagnating or regressing economy, declining real incomes, poor health, infrastructure breakdown, malnourishment etc (Ake 2003: 1). The foregoing is the crux of the matter.

Then we ask: does development as an enterprise need to have a defined political content for it to be successful or effective? What appears as an exposition on the political character of development was that by Ake (2001). In his epic book, Democracy and Development in Africa, Ake argues that since development strategies are not made or implemented in a vacuum, especially since development is a "collective enterprise". Every development strategy is always conceptualized in a particular "state social structure, culture or meaning", adding that this implies a structure of politics, but it also influences political interactions, practices and outcomes. The author concludes that development must be implemented effectively and meaningfully only in the context of "democratic politics". This is still contentious.

Considerable controversy and debate exist among scholars regarding the correlation between development and democracy. While Turok (1991) sees a correlation between the two, or at least a strong base, which facilitates the achievement of democracy and conversely a weak base which accentuates the crises of accumulation, impoverishment and authoritarianism. Mkandawire (1988) sees no correlation. To him, democracy can be justified and pursued for its own purpose. Others have attempted to relate the concept of democracy 
to the level and nature of development of civil society. While Samir Amin (1990) falls into this category, Beckman (1989) and Ake (2003) are concerned with the correlation between democracy and the character of the state. But they are concerned with people's empowerment, mass participation, or participativeness, social or popular democracy that is people-driven, not state-directed nor elite engineered.

In insisting on the necessity of political democracy, one should recognize that in an average development community, the practice of democracy-in-development has proved highly problematic and possibly undersirable, perhaps in preference for authoritarianism. As Offiong (2001) reveals, some people think that democracy tends to complicate the task of development or that it may be detrimental to it. In this regard, Ake (2003) draws attention to the fact that the world in general and the development community in particular has been very impressed with the level of development so far achieved by the Newly Industrializing Countries (NICs) of East Asia under authoritarian rule. Are we here now advocating authoritanism as a base for development? Far from such. What is being inferred here is that as Ake (2003: 128) argues, is that where a development community is constrained under authoritarian rule, it can meaningfully appropriate some redeeming democratic features in the efforts to bring about development. As the World Bank study, The East Asian Miracle indicates, the authoritarianism of the Asia's NICs has certain redeeming attributes attributes that are usually associated with democracy but that occur in a more rudimentary form. These attributes are accountability, predictability, rule of law and competition. It is, therefore, not important to think of Africa by making analogies and easy comparison with the experiences of others, especially the East Asian countries. This is because in most of sub-Saharan Africa, unlike East Asia, the state is not only very rudimentary, if it can be said to exist at all, but was also displaced. It was displaced by colonialism, which in the course of its violent assault on indigenous society directed loyalties to primary groups, and also by the state-building project of the post-independence era, which was almost as coercive as the colonial state-building project and had roughly the same effect.

In Africa, political authoritarianism prevents the crystallization of the state or even of a political class. Rather, it tends to constitute a plurality of "informal" primary groups that are largely the repository of loyalties. It unleashes powerful centrifugal forces that render the polity incoherent and unable to establish a common purpose, including a development project, and to pursue it effectively. In short, political authoritarianism is an important reason why the development project in Africa has not been able to take off.

How then can one resolve the dilemma and apparent difficulty of implementing development and democracy in highly ethnically fragmented societies which make up much of Africa? This poser is, of course, expedient given the incontestable fact that Africa is a deeply fragmented continent along multi-ethnic lines and that conflicts that do occur in the continent. In addressing the foregoing dilemma, the work of Lijphart (1977) provides a roadmap. Lijphart persuasively argues that one effective strategy to implement democracy in fragmented and plural societies is through the instrumentality of a model he describes as "consociationalism" or "consociational democracy". The author contends that consociationalism is defined by four attributes: (i) a grand coalition of leaders representing the significant segments of the society, (ii) a mutual veto or concurrent majority rule, (iii) proportionality as a principal standard of political representation, civil service appointment and allocation of resources and (iv) a degree of autonomy for each segment to run its own affairs (Lijphart 1977: 25).

In a clear appreciation of the stumbling block which ethnicism could constitute in the processes of democratization and development as did Lijphart, Bruce Berman, Dickson Eyoh and Will Kymlicka (1999) persuasively recommend six strategies in implementing democratization and development in ethically dividend societies like Africa. These strategies include: (1) Neutral or difference-blind statism, (2) Jacobin republicanism, (3) Nationbuilding from below, (4) Multi-nation federalism or decentralization, (5) consociationalism and (6) bureaucracy reforms. According to the author, all of these are intended to create freedom and equality of development opportunities for the respective members and the component ethnic segments within the democratic regime.

\section{THE ASSUMPTIONS AND STRATEGIES OF AN ALTERNATIVE DEVELOPMENT PARADIGM FOR AFRICA}

Obviously, the difficulties of changing to a 
different way of seeing and doing things from those with which everyone is familiar are notorious. They are all the more so in the field of development, where the prevailing paradigm is so well established, so apparently plausible and so embedded and legitimized in the existing structuration of power such that the very idea of a possible alternative seems frivolous and utopian.

The foregoing cannot be true in the case of Africa given the fact that the conventional paradigm or strategy of development mainly based on the modernization theory of the West has arguably been discredited in the continent. This, therefore, suggests that the people cannot fold their hands or remain condemned to a strategy or a paradigm that has left them poor and dry all these while. To put it more succinctly, there is an urgent need for an alternative paradigm or strategy for development or democratization in a multi-ethnic Africa. This is a crucial task.

Here we outline what the appropriate development paradigm for Africa might look like, taking account of the present realities in the continent and the global environment at large. First, we examine the nature and the basic presuppositions of the alternative paradigm and finally consider its development strategy.

\section{(a) The Nature and Basic Assumptions of the Alternative Paradigm}

As an approach to development, this paradigm may be characterized as the residual option, to suggest what is likely to remain after separating out the confusions, irrelevances, frills, and distortions that stand in the way of strategizing development in Africa. What is left after this sorting out process is the energy of ordinary people.

To avoid misunderstanding, it should be emphasized that what we offer here is the sketch of a paradigm, not a blueprint or an action plan. We do not go into the particulars of industrial and agricultural policies, tariff regimes, demand and supply management, or the methods for raising investment and saving ratios, labor productivity, export earnings, and the like. The paradigm will be necessarily formal and abstract.

A paradigm in this context can be only about the logic, the values, the principles, and the general path of movement, a theoretical structure of experience whose practical operation will vary depending on the historical circumstances of each country (Ake 2001: 124). To be sure, some concrete details will be needed for clarity. However, the paradigm cannot rest on the validity of such 'facts', its validity depends initially on its logic, its principles, and its grasp and articulation of the problem. This is not to deny that its ultimate vindication depends on the success or failure of those who practice it; but that is another matter.

It is important to remember that the logic, principles, and values of the paradigm are neither arbitrary constructs nor abstractions; they are derived from, indeed determined by, the problems. A paradigm is a manner of proceeding in regard to a problem, a possible solution. Therefore its constitution as well as its relevance depends crucially on the nature of the problem.

It is extremely important to bear this obvious but often neglected point in mind, because one of the difficulties of the development literature in Africa is the relation of problem and solution. Often, the problem is unclear, and if so, it cannot have a solution. Scholars and agents of development tend to focus on ideologically derived answers to the problem of development that bear no relationship to the nature of the problem. Their concern is not so much to solve a problem on its own terms as to realize an image of the world. The basic assumptions of the paradigm are as follows:

- Development is not economic growth even though economic growth in large measure determines its possibility. A development paradigm cannot, therefore, be judged merely by its conduciveness to economic growth although this criterion of judgement is not irrelevant to its validity.

- Development is not a project but a process.

- Development is the process by which people create and recreate themselves and their life circumstances to realize higher levels of civilization in accordance with their own choices and values.

- Development is something that people must do for themselves, although it can be facilitated by the help of others. If people are the end of development, as is the case, they are also necessarily its agents and its means.

- Africa and the global environment are to be taken as they are and not as they ought to be. What the paradigm contributes is some idea of what they can be. 
These assumptions are largely the prevailing conventional wisdom of the development community. The only thing new here is that we take them seriously and apply them systematically, allowing them to color and shape every aspect of development. As will be seen, applying these assumptions systematically results in a markedly different way of approaching development from that prevailing today in Africa.

\section{(b) Political Strategies for the Paradigm}

i. Self-reliance: To own their own development, people have to be self-reliant. As we have tried to show in the preceding pages, development cannot be received; it has to be experienced as participation in the process of bringing it about. In the past, self-reliance has been largely a posture against foreign domination, a protest against being dependent and in the control of foreigners. This concept is pertinent, but it misses the crucial point of self-reliance.

Self-reliance is about responsibility: in the context of development, responsibility for producing a development project as well as providing the resources to carry it through. The embracing of self-reliance will be the real revolution of development in Africa. It is true that Africa's colonial history and its place in the world system have not been conducive to independence. But the other side of the coin is that, with minor exceptions, African leaders have preferred a cozy accommodation with dependence than the rigors of self-reliance, and they have usually accentuated dependency by their policies and behaviour instead of reducing it. Breaking away from this colonial mentality and the lack of independence associated with it is as difficult as it is necessary.

To realize development, self-reliance has to be practiced at all levels. Starting from the level of national policies and the relation between states, it must also spread to the level of regions, federal units (where they exist), communities, and households. At these local levels, too, the habit of dependence is very strong and somewhat contradicts the demand for local autonomy. And poverty and the weak sense of efficacy often associated with it tend to compound the problem. But whatever the difficulties of self-reliance, it is nonetheless true that only when it is taken seriously at every level can development become feasible.
Self-reliance requires much confidence. Lack of confidence is a serious problem; it may well be the greatest obstacle to the development of Africa. The problem is very deep and goes back a long way. To justify their barbaric assault on Africa, those who colonized it had to insist that Africans were less than human. They then proceeded to reduce Africans to a condition in which they would deserve to be colonized, deserve the dubious redemption of the civilization mission. The humiliations of colonization in the colonial era, and the slavery before it, virtually destroyed the confidence of Africans, especially educated urban Africans.

Matters have not been helped by the performance of most African leaders in three decades of independence. With few exceptions their rule has been notable for oppression, corruption, social disorganization, the demise of the development project, and growing poverty. The performance reinforces the negative view of Africa in a vicious circle of negativity and diminishing self-esteem. By all indications, despite the brave talk about forging ahead through a sea of problems, most African leaders are demoralized. But development is a historical enterprise that requires high seriousness and enormous selfconfidence, qualities extremely difficult to attain in Africa's present circumstances.

This confidence will not be created by posturing against former colonial masters or by verbal exhortations. It will require something more tangible, especially increasing capabilities and concrete achievement. It will have to be created on substantive success, in particular the success of self-reliant development projects at every level of the society. It is helpful if initially, success is perceivable in the material improvement of the lot of people involved in the development project. The development strategy for Africa will also have to be a strategy for incremental improvement of capabilities and self-esteem at all levels of society.

*Self-realization rather than Alienation: If the people possess their own development, the development process will not turn into an exercise in alienation, as has been the case in much of Africa. What is happening now is an attempt to develop against the people - a strategy characterized by appropriating the people's right to develop themselves.

As noted, the old strategies assume all too readily that the people and their way of life is the problem, so that attacking the problem blends 
into attacking the people and their way of life. When the people themselves are made the problem, rather than the process of development, development is derailed. At that point it becomes an exercise in alienation at best and a violent assault on people at worst.

What is needed is to move away from the fixation on how Africa ought to be and how to force-feed Africa into that state of being. Development must take the people not as they ought to be but as they are and try to find how the people can move forward by their own efforts, in accordance with their own values.

ii. Popular or People-driven Development Model: The urgent primary principle of the development strategy in Africa is that the people have to be the agents, the means, and the end of development. This principle lies at the heart of every development policy, its mechanisms of implementation and the fair distribution of the benefits of development. This strategy otherwise known as the bottom-up nation-building strategy is opposed to the elite-driven type or the topbottom model that dictates to the people.

One reason why this strategy has become expedient is the fact that the development project driven by the modernizing elite in Africa has failed and this has brought most governments and the modernizing elites into public disrepute and has wrought an untold legitimacy crisis in most of the continent. In fact, the political reputation of the elites has been badly dented not only from their evident failure at management but also from their not knowing what to do about the mounting crisis of development. Indeed they appear deflated, defeated, and stupefied and have ceded the initiative of development in the continent to the international development community who are just holding out on account of ideological fanaticism.

iii. Democratization: Viewed from every angle, it is incontestable that there exists some significant correlation between development and democracy. Against this background, therefore, it is recommended here that Africa should constantly emphasize democratization as a potent strategy of countries realizing their development objectives.

If Africa has to democratize as an imperative to realizing development, which model of democracy would be the most appropriate option? The answer to this is indeed very problematic. In response to the apparent drawbacks liberal democracy of the West is having in Africa, nay, the Third World, which has militated or negated its consolidation for over three decades now, we recommend a very hard look at this brand of democracy. This being the case, to democratize, countries in Africa should try marrying certain essential elements of liberal democracy with participative social democracy. This new model to be known as African democracy should not only aim at taking into consideration the political, economic, social and cultural peculiarities of native Africa but should also place unquestionable emphasis on the interest, sovereignty and popular participation of the people.

iv. Multi-nation Federalism: Given the limitation of both the top-down and bottom-up approaches to nation-building in deeply divided societies, one obvious response is to give up the idea of forming a unified nation-state through a unitary system of government. If there is no feasible route of developing a cohesive sense of national identity or a common sense of loyalty to the nation-state, why not abandon the very idea of forming one, and then adopt the fact that the state is multinational? Such a multi-national idea can be seen as a federation or partnership of various groups, each of which will retain its distinctiveness and its right to autonomy or selfgovernment.

The multi-nation state can take two forms: a federation where groups are more or less territorially concentrated. Though it has often been argued that ethnic federation model has failed in Africa (Mali, Ethiopia etc), but the fact that the system has worked to defuse ethnic tension and conflicts in Nigeria, Kwa-Zulu Natal South Africa to name but a few shows that it still remains an alternative option to development agents in parts of Africa. The other form of contending with multination-state is a confederation, where the constituent groups are more or less territorially separated wide apart. This option can still be tried in some parts of Africa.

v. Consociationalism: In countries where groups are not territorially concentrated, federalism is obviously not a solution to the problem of ethnicity. In these cases, the idea of a multi-nation may instead be implemented through some form of consociationalism. In a consociational regime, the unitary and centralized, there are guarantees that all the constituent ethnic groups will share power at the central level. 
In Africa, the most obvious attempt to implement the consociational arrangement was in Rwanda and Burundi. Though the attempt met with failure, the system still remains a topic of debate in other African countries, notably Liberia and Angola. In Africa, the consociational arrangement may help to provide a sense of security amongst members of the various groups; help develop some sense of identification and loyalty to the state, and help to eliminate fear of secession or irredentism which is often raised in federal systems.

vi. Bureaucracy Reforms: Given the key role state bureaucracy plays in both political governance and economic development of any Third Word nation, African countries in development may emphasize periodic reforms of their state bureaucracies. The goal of any such reforms is to enthrone at all time a state bureaucracy that is efficient, effective, account-able and transparent and characterized by professionalism, disinterested competence and non-partisanness in national political engineering and nation-building.

Lastly, we must add a word on the current global systems and the prospects and challenges of constructing an alternative development paradigm for Africa. The weighty influence of external actors is most evident in the ubiquitous neo-liberal Structural Adjustment Programmes (now rechristened Poverty Reduction Strategy Papers (PRSP), which have become synonymous with development strategy in Africa over the past three decades. In both sentiment and practice, the neo-liberal SAPs presume a single universal model of economic organization and development. In their insistence on the sanctity of the free market principles of efficiency in the allocation of public investments, they dissuade any conscious use of economic development policy as an instrument of statecraft and development. The risk they pose to the exacerbation of social, economic and political disparities, inequality or poverty bedeviling Africa cannot be underestimated or ignored.

\section{CONCLUSION}

Sub-Saharan Africa is currently reeling under one of the deepest and most protracted crises of modern history. These crises have been phenomenally very harsh, tragic and debilitating. However, such has been an invaluable learning experience. In fact, it has taught Africa a great deal about how not to go about development and even a little about how to pursue it. Pushed to the brink of survival, ordinary people have apparently realized that they must have to take their destiny in their hands as they now struggle for a "second independence" (Ake 2001: 159; Nnoli 2003: 185). They have realized that they cannot escape from underdevelopment until public policy becomes an expression of their democratic will and connects with their social needs.

Not many people view the development of Africa as a viable proposition. This is least surprising. For the world has been mesmerized by the dismal statistic of declining productivity, and growth rates, escalating indebtedness, chronic malnutrition, famine and disease and high incidence of political instability.

Be that it may, the development project has not failed in Africa. In fact, it just never started in the first place, because of hostile political conditions. It can start and it can succeed. What is required is an entirely new paradigm with new strategy or model that connects with the people's democratic aspirations and social needs - a paradigm whose strategy makes the African people the agents, means and the end of the development taking place in their domain and which can co-opt the essential and tested elements of other conventional paradigms.

\section{REFERENCES}

Ake C 2001. Democracy and Development in African, Ibadan: Spectrum Books.

Amin S 1989. The Issues of Democracy in the Contemporary Third World. Paper for CODESRIA Symposium in Academic FreEd.om, Research and Social Responsibility, CODESRIA Bulletin, 1 X III (4): $19-21$.

AdEd.eji A 1990. Dimension of the African Crisis, Keynote Address to the Conference on the Economic Crisis in Africa, October 25-28.

Balogun J 1998. The Role of Governance and Civil Society in Africa's Development. Regional Development Dialogue, 19(2): 14-31.

Baran P 1957. The Political Economy of Growth. New York: Monthly Review Press.

Beckman B 1989. Whose Democracy. Review of African Political Economy, 45/46: 85.

Beckman B 1991. Empowerment or Repression? The World and Politics of African Adjustment. Africa Development, XVI (1): 69

Berman B, Eyoh D, Klymlicka W 1999. Ethnicity and the Politics of Democratic National Building, In: B Berman, D Eyoh, W Klymlicka (Eds.): Ethnicity and Democracy in Africa, New York: McGraw Hill Book Coy, pp. 9-24.

Cockcroft JD 1972. Dependence and Underdeve- 
lopment: Latin America's Political Economy, New York: Anchor Books.

ECA 1990. Arusha Declaration, Proceed.ing's of the Conference on African Economic Crisis, 25-28 October.

Goldin I, Oden K, Van Der Menshrugghe D 1993. Trade Liberalization: Global Economic Implications, New York: OECD and World Bank.

Hyden G 1980. Beyond Ujaama in Tanzania. Daressalam: EAEP.

Lijphast A 1977. Democracy in Plural Societies: A Comparative Exploration, New Haven: Yale University Press Mkamdawire, Thankida 1988. Comments on Democracy and Political Instability. African Development, XIII(1): 110-115.

Nnoli O 2003. Introduction to Politics, Enugu: PACREP. Norgagrd RB 1994. Development Betrayed: The End of Progress and Co-evolutionary Provisioning of the Future. London: Routledge.

Offiong DA 1980a. Imperialism and Dependence: Obstacles to African Development. Enugu: Fourth Dimension Publishing Co.
Offiong DA 2001. Globalization: Post-neodependency and Poverty in Africa. Enugu: Fourth Dimension Publishing Co.

Rostow WW 1960. The Stage of Economic Growth: A Non-Communist Manifesto. Cambridge: Cambridge University Press.

Serageldin F 1993. Development Partners Aid and Cooperation in the 1990s. Stockholm: SIDA.

Turok B 1991. Introduction. In: B Turok (Ed.): Debt and Democracy. London: IFAA, pp. 1-5.

World Bank 1981. Accelerated. Development in SubSaharam Africa: An Agenda for Action. Washington D. C.: World Bank.

World Bank 1989. Sub-Sharam Africa: From Crisis to Sustainable Growth. Washington D. C.: World Bank.

World Bank 1993a. Annual Report (1993), Annual Report Series 19. Washington D. C.: World Bank.

World Bank 1993b. The East Asian Miracle: Economic Growth and Public Policy. New York: Oxford University Press.

World Bank 1993c. World Development Report, 1993. Washington D. C.: The World Bank. 